\title{
HISTOPATHOLOGY OF BRAIN, EYES AND INTESTINES IN CANTANG GROUPER (EPINEPHELUS FUSCOGUTTATUS X E. LANCEOLATUS) EXPOSED TO VIRAL NERVOUS NECROSIS THROUGH THE ADDITION DUNALIELLA SALINA ON DIETARY
}

\author{
Yuwanita Rani, Rahardjo S.S.P., Effendi V.I.A. \\ Faculty of Fisheries and Marine Science, University of Brawijaya, Indonesia \\ Plygun S. \\ European Society of Clinical Microbiology and Infectious Diseases, \\ Basel, Switzerland \& Laboratory of Biocontrol and Antimicrobial Resistance, \\ Orel State University named after I.S. Turgenev, Orel, Russia \\ *E-mail: raniyuwanita@ub.ac.id
}

\begin{abstract}
This research aimed to determine the effectiveness of Dunaliella salina extract in reducing the damage of the brain, eyes and intestines tissue of cantang grouper infected with VNN. Fifty seeds of cantang grouper were stocked into 5 pieces of $50 \mathrm{~L}$ volumes with a density of 10 fish/container. Before being infected with VNN, the groupers were treated with feed containing $D$. salina extract with a dose: K- $(0 \mathrm{mg} / \mathrm{kg}$ feed), A (250 mg/kg feed), B (300 $\mathrm{mg} / \mathrm{kg}$ feed), C (350 mg/kg feed) and D (400 mg/kg feed) for 10 days. After 10 days of treatment, cantang groupers were injected by VNN through intramuscular injection with a dose of $0,2 \mathrm{ml} /$ fish with concentration $10^{4}$. Based on the research, $D$. salina extract which added into feed was effective in reducing the percentage of histopathological damage in the brain, eyes and intestines tissue of cantang groupers infected with VNN. The histopathological damaged tissue was necrosis, vacuolation, inclusion body, congestion, and goblet cell. The results showed that the lowest damage in the brain, eyes and intestine were found in treatment D (400 mg/kg of feed) with a percentage of damage $6,8 \%, 7 \%$ and $12,8 \%$.
\end{abstract}

\section{KEY WORDS}

Dunaliella salina, histopathology, grouper, VNN.

Groupers are one of the most important fishery commodities that have a very high export demand, although they are relatively expensive (Dewi, et al., 2018). The number of grouper fish production in Indonesia during 2012 was up to 269.179 tons and had increased to 578.776 tons in 2017 (Ministry of Maritime Affairs and Fisheries, 2017). Cantang grouper is a type of hybrid grouper that faster growth with lower FCR compared to tiger and kertang grouper (Triastuti, et al., 2018). The growth of cantang grouper can reach $724 \%$, whereas in tiger grouper only 295\% (Khumaidi, et al., 2019).

However extensive and intensive culture of groupers are plagued by a number of viral pathogens like Viral Nervous Necrosis (VNN) which attacks groupers during seed stages and kills $97-98 \%$ of the total fish population (Munday, et al., 1992). VNN belongs to the genus Betanodavirus, family Nodaviridae (Nakai, et al., 2009). Betanodavirus are icosahedral, nonenveloped with diameter of 23-25 nm and the genome consists of 2 single-stranded of positive-sense RNA (Fenner, et al., 2006). The larger genomic segment (RNA1) has size of $3,1 \mathrm{~kb}$ and a role in encodes RNA-dependent RNA polymerase, while the smaller genome segment (RNA2) has size of $1,4 \mathrm{~kb}$ encodes a protein coat (Nizhisawa, et al., 1995). VNN attacks the central nervous system in fish, causing abnormal behavior such as whirling and often stayed on the bottom to cause death (Doan, et al. 2016).

The use of natural ingredients mixed into feed is highly recommended in preventing the spread of VNN in order to improve immune function and disease resistance (Alishahi, et al., 2015). One of the natural ingredients that can be used to improve nutrition is microalgae 
Dunaliella salina which contain the highest $\beta$-carotene compared to other types of microalgae that is equal to $14 \%$ of the dry weight and has benefits an antioxidant for the immune system (Bhattacharjee, 2016). Giving $300 \mathrm{mg} \beta$-carotene Dunaliella per $\mathrm{kg}$ of feed produces the highest survival rate on a fish or shrimps infected with a virus that is equal to $33.3 \%$ (Supamattaya, et al., 2005). D. salina also contains napthalene as an effective antimicrobial against pathogens (Rokade and Sayyed, 2009), whereas the phenolic compounds can be useful in the prevention of diseases involving free radicals by reducing stress and inhibit the oxidation of macromolecules (Pereira, et al., 2007). Other contents were found in the form of $\alpha$-carotene, $\beta$-carotene, lutein and zeaxanthin was $28.8 ; 471.1 ; 7.1$ and $7.2 \mathrm{mg} / \mathrm{g} D$. salina extract (Yang, et al., 2013). D. salina also contain $12-40 \%$ polysaccharide which used as anti-tumor and antiviral (Dai, et al., 2010).

Effectiveness $D$. salina as antivirus can be seen from histopathological parameters. This method is used to detect the presence of pathogens through micro anatomical observations to show abnormal changes at the tissue level (Yuwanita, et al., 2013). Overview of virus infection, either in cells or tissue can be used as an early warning sign of a disease and determine the right handling method (Gupta, et al., 2009).

\section{MATERIALS AND METHODS OF RESEARCH}

Preparation and extraction. D. salina flour was obtained from BPBAP Situbondo. This examination was conducted in April 2019 at the Laboratory Fisheries Resource Exploration (Brawijaya University, Malang). The extraction process with maceration. 450 gram of flour soaked with $2250 \mathrm{ml} \mathrm{n}$-hexane (PA) solvent (1:5) for $1 \times 24 \mathrm{~h}$. Extracts are filtered using filter paper and evaporated with a vacuum rotatory evaporator at $50^{\circ} \mathrm{C}$.

Repelleting. D. salina extract was added to pellet with doses $\mathrm{K}-(0 \mathrm{mg} / \mathrm{kg}$ feed), A (250 $\mathrm{mg} / \mathrm{kg}$ feed), B (300 mg/kg feed), C (350 mg/kg feed) and D (400 mg/kg feed) then mixture was grinded. After repelleting, the new compound feed was dried and stored before used.

VNN isolation. The mixture of VNN-suspect eye or brain of cantang grouper and PBS $\mathrm{pH} 7.2$ (1:3) was homogenize. The homogenate centrifuged at $3000 \mathrm{rpm}$ for 10 minutes. Obtained supernatant centrifuged again at $12000 \mathrm{rpm}$ for 30 minutes. Next, supernatant filtered using $0.45 \mu \mathrm{m}$ membrane filter. The results of VNN isolation were stored in freezer $80^{\circ} \mathrm{C}$ before being used to inject cantang grouper.

Cantang grouper. In this research, 50 seeds cantang grouper with size of $7-9 \mathrm{~cm}$ was provided by BPBAP Situbondo. Initially, grouper were acclimatized under $50 \mathrm{~L}$ container with neutral $\mathrm{pH}$, range temperature, dissolved oxygen (DO), salinity and aerated (Adipu, et al., 2013) for one week. After a week, cantang grouper fed with pellets that contain $D$. salina extracts twice a day for 10 days. In addition, measurement of temperature, $\mathrm{pH}$, salinity and DO to control the water quality. After 10 days, cantang groupers were injected by VNN through intramuscular injection with a dose of $0,2 \mathrm{ml} / \mathrm{fish}$ with concentration $10^{4}$.

Histopathology observation. A positive sample and normal brain, eyes and intestines of these larvae cantang grouper infected by VNN were collected and fixed in Davidson's solution. After dehydration and clearing, samples were embedded into paraffin wax using automatic tissue processor. Paraffinated blocks were further processed in order to prepare 5 micron section using microtome which then stained by haematoxylin and eosin staining method and observed by light microscope.

Data Analysis. Histopathological alterations were assessed using a score ranging from 0 to 3 depending on the degree and extent of the alteration: (0) none, (1) less than $30 \%$ of occurrence, (2) $30-70 \%$ of occurrence, (3) more than $70 \%$ of occurrence (Pantung, et al., 2008). Based on the scoring it can be seen the effect of giving $D$. salina extracts into pellets to reduce tissue damage due to VNN infection.

\section{RESULTS AND DISCUSSION}

Figure 1 shows the normal and infected cantang grouper brain tissue. The structure of normal brain doesn't show any damage, while infected organ shows some damage. 

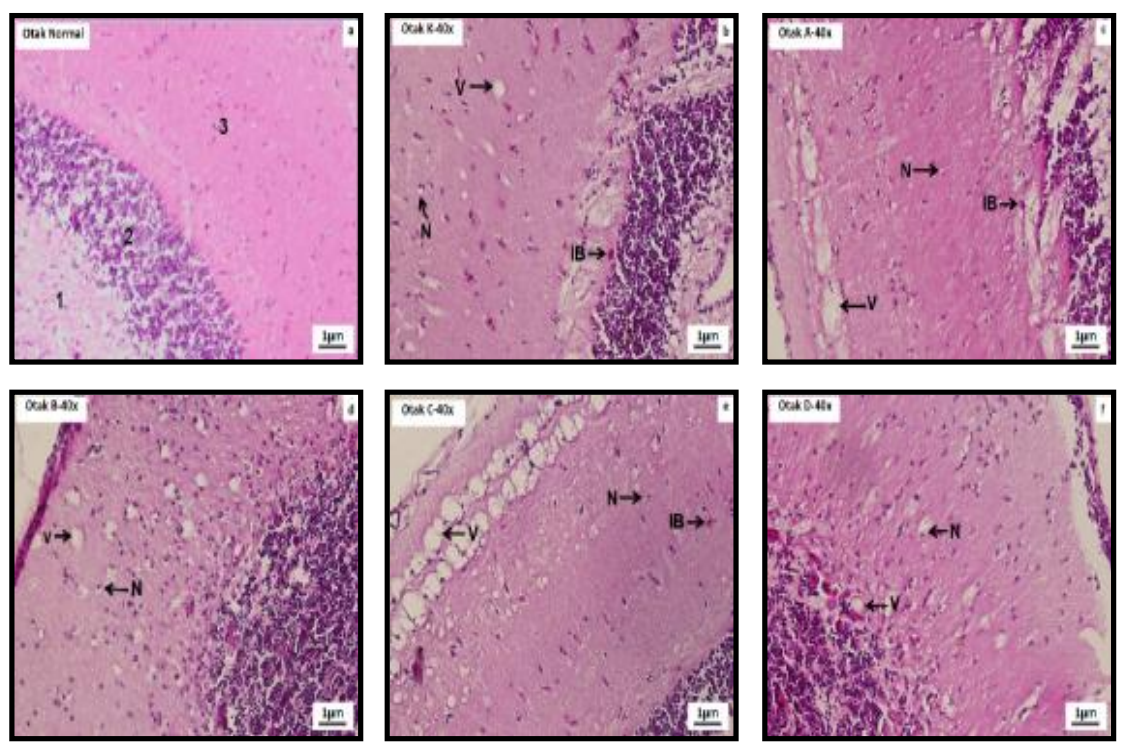

Figure 1 - a) Normal tissue, b) K- (0 mg / kg diet), c) A (250 mg / kg diet), d) B (300 mg / kg diet), e) C (350 mg / kg feed) f) D (400 mg / kg diet). Note: V) vacuole, (N) necrosis, (IB) inclusion body.

H\&E magnification of $400 x$

Necrosis is unregulated cell death, characterized by plasma membrane rupture as well as nuclear and cellular swelling. Necrosis can cause by viral infection (Shin, et al., 2015). Necrosis can be identified from the nuclear shrinkage or pyknosis, the nuclear fragmentation or karyorrhexis and nuclear fading karyolysis (Ajayi, et al., 2018). Based on observations, the most visible damage necrosis is to the stage of karyorrhexis. Damage to vacuoles is characterized by the presence of empty spaces (Purcell, et al., 2018). VNN attack the nerves of the brain, thereby damaging fish motor and impact on the fish body performance system (Chi, et al., 1997). Irregular movement of fish can be related to the presence of vacualtion in brain cells undergo necrosis due to VNN infection (Nazari, et al., 2014). In addition, damage was also found in the form of inclusion body. Cells infected by the virus can form inclusion or occlusion body in infected cells during replication. Some are formed as a result of the accumulation of virions, although some inclusion bodies may not contain virions (Yuwanita, et al., 2013). Inculusion body can be divided into three types: smudge-type (like stain), fulltype and cowdry A (only partially) (Abe, et al., 2011).

To know the level of damage on brain of cantang grouper, scoring table is shown in table 1 below.

Table 1 - Scoring Damage of Brain Tissue

\begin{tabular}{cccc}
\hline Dose $(\mathrm{mg} / \mathrm{kg})$ & Total damage $(\%)$ & Score $^{*}$ & Level of damage $^{\star}$ \\
\hline 0 & 17.4 & 1 & Low \\
250 & 16.2 & 1 & Low \\
300 & 14.2 & 1 & Low \\
350 & 8.8 & 1 & Low \\
400 & 6.8 & 1 & Low \\
\hline
\end{tabular}

*Notes: Score 0 normal category that there are no damage at all, score 1 low category is damage to $<30 \%$, a score of 2 category was that damage to between $30-70 \%$, a score of 3 categories, namely heavy damage to> $70 \%$ of the field of view (Pantung, et al., 2008).

The difference of percentage obtained due to the higher dose of $D$. salina added the less tissue damage caused by VNN. One of the compounds found in $D$. salina extracts is a phenol which functions as antioxidants. Phenol compounds are believed to react with free radicals to donate hydrogen atoms, so that the phenolic compounds can be stable again. That's why phenol become unreactive and can be used as an antioxidant. With the presence of phenolic compounds it is possible damage to membrane lipids, proteins and DNA will be inhibited (Hashemi, et al., 2019). This is accordance with the opinion of Devi, et al. (2018), 
which states that by adding $D$. salina through fish feed can significantly increase the immune response when compared to feed that is not given $D$. salina. $D$. salina extract also increase the activity of Natural Killer cells that play a role in phagocytic in fish bodies to reduce the spread of the virus at the infection stage (Chang, et al., 2011).

The observations to identify the damage on eyes of cantang grouper is shown in Figure 2, while histopathological scoring shown in Table 2.
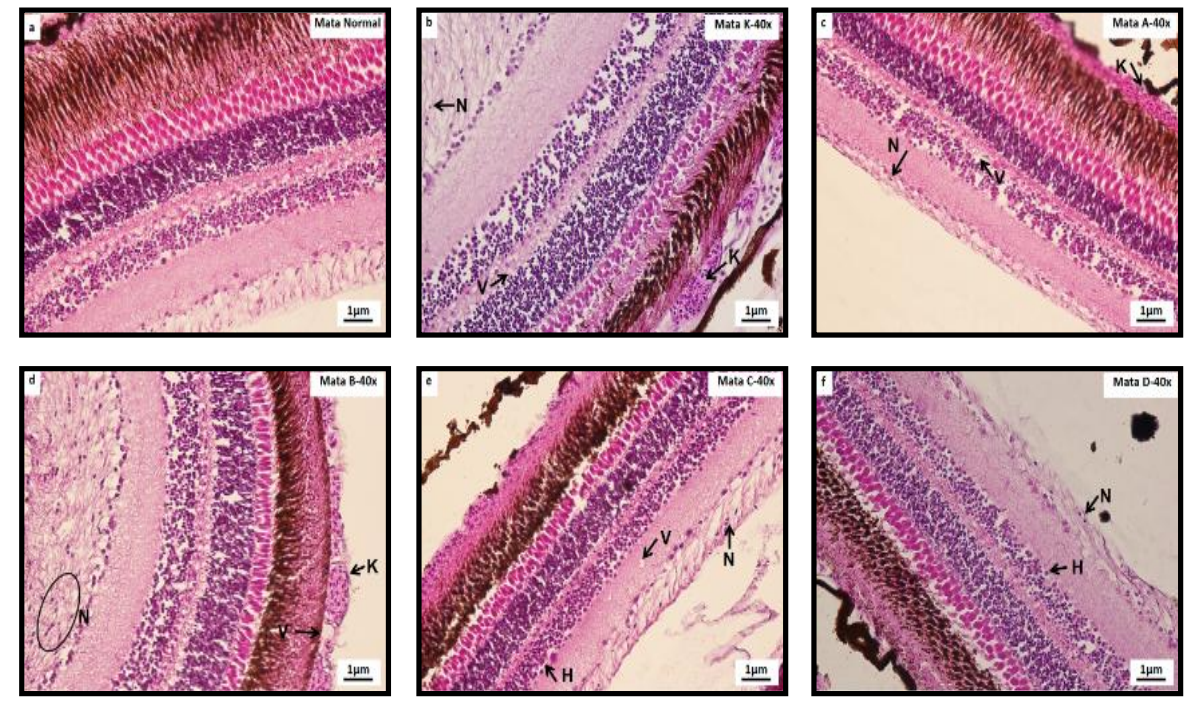

Figure 2 - a) Normal tissue, b) K- (0 mg / kg diet), c) A (250 mg / kg diet), d) B (300 mg / kg diet),

e) C (350 mg / kg feed) f) D (400 mg / kg diet). Note: V) vacuole, (N) necrosis, (K) congestion. H\&E magnification of $400 x$

Necrosis is a type of chronic tissue damage that is irreversible. The morphology of necrosis is characterized by swelling of the cell organelles and the loss of plasma membrane integrity. This damage may reduce the ability of cells to produce ATP (Zong and Thompson, 2006). Necrosis of the cells caused by the activity of phagocytosis of lymphocytes that cause shrinkage or nucleus overall size reduction (Takashima and Hibiya, 1995). Necrosis on a organ tissue will result in the loss of function in areas of necrosis (Prince and Wilson, 2006).

Vacuole is an area that is colorless and appear as holes in the cytoplasm (Praveenraj, et al. 2018). Vacuoles known as damage due to pathogen infection in conjunction with cell death and irreversible (Shubin, et al. 2016). The same result was shown by Yuwanita, et al. (2013) that vacuole occurs in infected grouper VNN at the granular layer of the retina of the eye. Damage to congestion was found as swelling of the blood vessels and filled with erythrocytes (Robert, 2001). Excessive congestion can cause hemorrhage. This swelling is caused by blood flow tends to be slow and stagnant. Eventually tissue oxygenation will be lost and in a long time it can cause rupture of blood vessels to spread to other tissues (Zachary, 2017).

Table 2 - Scoring Damage of Eye Tissue

\begin{tabular}{cccc}
\hline Dose $(\mathrm{mg} / \mathrm{kg})$ & Total damage $(\%)$ & Score $^{\star}$ & Level of damage $^{*}$ \\
\hline 0 & 16 & 1 & Low \\
250 & 13.6 & 1 & Low \\
300 & 12.2 & 1 & Low \\
350 & 8.2 & 1 & Low \\
400 & 7 & 1 & Low \\
\hline
\end{tabular}

*Notes: Score 0 normal category that there are no damage at all, score 1 low category is damage to $<30 \%$, a score of 2 category was that damage to between $30-70 \%$, a score of 3 categories, namely heavy damage to> $70 \%$ of the field of view (Pantung, et al., 2008).

Differences in the results obtained due to the administration of $D$. salina different extracts into the feed that can increase the non-specific defense cantang grouper. The higher 
dose of $D$. salina extract, the less the percentage of tissue damage caused by the VNN. $D$. salina extract can improve leukocyte (non-specific defense) cantang grouper so that the virus doesn't cause complex damage to the eye tissue. The higher level of virulence VNN, the production of ROS (Reactive Oxygen Species) also may increase and damage the mitochondria until finally cell death occurs. ROS is a cause of cell death that begins with the appearance of oxidative stress by mitochondria where it will have an impact on antioxidant enzymes that exist in the host body and lead to necrosis. If the amount of ROS in the body continues to increase, it can cause damage to cells. Therefore, to overcome it happens needed antioxidants such as phenolic compounds contained in extracts $D$. salina to suppress the excessive production of ROS (Chang, et al., 2011). Dunaliella sp. contains carotene that can improve SR and increase antioxidant activity (Emadi, et al., 2010). In addition, the content of $\beta$-carotene in $D$. salina can inhibit the accumulation of spots on blood vessels in the tissue so that blood flow runs smoothy (Yahya and Wiryanta, 2005).

Based on research, cantang grouper intestine tissue, showed a difference between normal tissue and those that have been infected by VNN (Figure 3). After that, to know the level of intestine damage scoring is done as shown in Table 3.
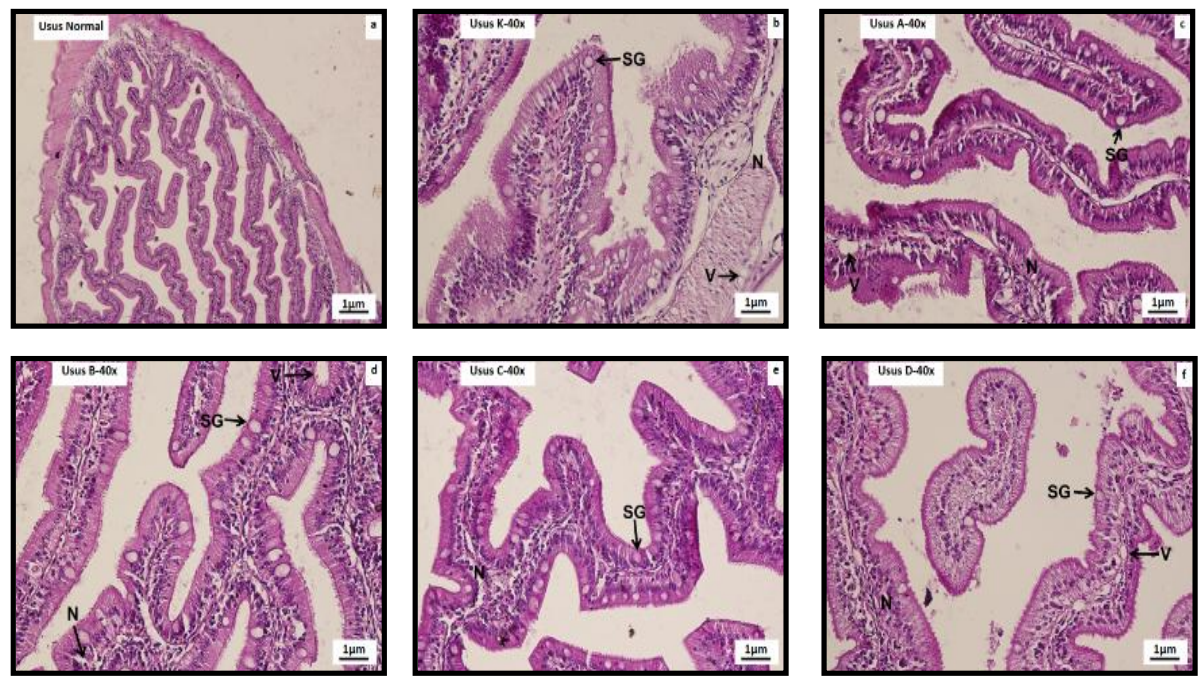

Figure 3 - a) Normal tissue, b) K- (0 mg / kg diet), c) A (250 mg / kg diet), d) B (300 mg / kg diet), e) C (350 mg / kg feed) f) D (400 mg / kg diet). Note: V) vacuole, (N) necrosis, (SG) goblet cells. H\&E magnification of $400 x$

Vacuoles and necrosis are not only found in the central nervous tissues, but were also found in the intestinal organs. The same opinion was explained by Murphy, et al. (2004), that the abnormal symptoms grouper due to virus are not only caused in the central nerve, but also in intestinal organs. The presence of necrosis in the intestinal tissue damage can be recognized from the loss of cytoplasm. Necrosis is characterized by dilated organelles, cell swelling and rupture of the plasma membrane. Necrosis classified as damage which is not regulated and happened by accident, depending on pathogenicity (Shen and Vandenabeele, 2014). Lesion to the digestive tract will affect the activity and function of digestive enzymes that will disruption the digestive process and absorption of food which can reduce fish growth (Khillare, et al., 1988).

Severe necrosis will cause the formation of vacuolation in the tissue. Vacuolation is characterized by non-nucleated empty space (Nazari, et al., 2014). At the stage of HE staining, tissue in diseased fish will appear to be broken due to vacuoles in these cells and the cytoplasm is no longer visible (Bodammer and Murchelano, 1990). Goblet cells are part of the intestinal mucosal layer and function to protect from mechanical and chemical damage, helps the absorption and transportion of molecules through the membrane, and protection against microorganisms (Arman and Acuncu, 2017). Mucus contains substances such as immunoglobulins, lisozym, C-reactive protein and lectin which is very important for 
the defense of disease or unfavorable environments (Rombout, et al., 1993). Goblet cells are oval and round, contains mucin which serves to lubricate the food, provide protection to the intestinal wall and a defense medium against pathogen infection. The increased numbers of goblet cells are stimulated by infection of VNN to produce more mucus as a non-specific defense (Gibson, 2016).

Table 3 - Scoring Damage of Intestine Tissue

\begin{tabular}{cccc}
\hline Dose $(\mathrm{mg} / \mathrm{kg})$ & Total damage $(\%)$ & Score $^{*}$ & Level of damage $^{*}$ \\
\hline 0 & 24 & 1 & Low \\
250 & 21.6 & 1 & Low \\
300 & 16.8 & 1 & Low \\
350 & 14.8 & 1 & Low \\
400 & 12.8 & 1 & Low \\
\hline
\end{tabular}

*Notes: Score 0 normal category that there are no damage at all, score 1 light category is damage to $<30 \%$, a score of 2 category was that damage to between $30-70 \%$, a score of 3 categories, namely heavy damage to> $70 \%$ of the field of view (Pantung, et al., 2008).

The administration of $D$. salina extract into the diet reduced the intensity of intestinal organ damage due VNN infection when compared to the control treatment. Carotenoids function essential for biological activity in the body. The compound has potential as an antioxidants, reduce free radicals and can prevent pathogenic attack. Although intestinal organs is not the target organ for VNN, but the digestive tract such as the intestine can be damaged due to the stress by the cantang grouper (Ahmad, et al., 2015). When cantang grouper in stressed conditions, they will produce a lot of free radical compounds known as ROS. The accumulation of ROS in greater numbers will harm cells and can cause death because ROS produces lipid peroxide reaction (Martinez-Alvarez, et al., 2005). Similar research by Supamattaya, et al. (2005), where the adding of $300 \mathrm{mg}$ of $D$. salina extract to shrimp feed will have a more tolerant effect on disease and low oxygen content because the carotene content can increase phagocytic activity.

\section{CONCLUSION}

Addition of $D$. salina extract into diet is effective in reducing the percentage of histopathological damage. The more dose of extract if given, the more damage is obtained to the tissue of the organ. In the brain, eyes and intestine organs, the lowest damage was obtained in treatment D $(400 \mathrm{mg} / \mathrm{kg}$ feed) with a percentage of damage of $6,8 \% ; 7 \%$ and $12,8 \%$ each. The dose $D$. salina extract of the studied can be used as potential leads to reduce histopathological damage in cantang grouper when infected with VNN.

\section{REFERENCES}

1. Abe T, Nishi S, Furukawa T, Ajioka Y, Masuko M and Fuse I 2011 Acute renal failure induced by adenovirus after stem cell transplantation. Hemodialysis- Different Aspects Intech. Open. 11-16.

2. Ahmad A S, Siong Y J F, Syamsumir D F, Zin N A M, Radzi S A M, Kassim M N I, Muzamel M A, Yusof M R and Segaran T. C 2015 The potential of carotenoids drom marine tropical microalgae in the healing process of gastritis J. Sustain. Sci. Manag. 10 (1) $92-106$.

3. Ajayi B B, Ogunsola J O, Olatoye O I, Antia R E and Agbedea S 2018 Effects of pituitary extract, ovaprim, and bitter leaf (Vernonia amygdalina) on the histopathology of African catfish (Clarias gariepinus) Aquacult. Fish. 3 (6) 232-7.

4. Alishahi M, Karamifar M and Mesbah M 2015 Effects of astaxanthin and Dunaliella salina on skin carotenoids, growth performance and immune response of Astronotus ocellatus. Aquacult. Int. 23 (5) 1239-48.

5. Arman S and Ucuncu S I 2017 Histochemical characterization of convict cichlid (Amatitlania nigrofasciata) intestinal goblet cells Pakistan. J. Zool. 49 (2) 417-424. 
6. Bhattacharjee M 2016 Pharmaceutically valuable bioactive compounds of algae Asian. J. Pharm. Clin. Res. 9 (6) 43-7.

7. Bodammer J E and Murchelano R A 1990 Cytological study of vacuolated cells and other aberrant hepatocytes in winter flounder from boston harbor Cancer. Res. 50 6744-56.

8. Chang C, Su Y, Her G, Ken C and Hong J 2011 Betanodavirus induces oxidative stressmediated cell death that prevented by anti-oxidants and zfcatalase in fish cells Plos. One. 6 (10) 1-10.

9. Chi S C, Lo C F, Kou G H, Chang P S, Peng S E and Chen S N 1997 Mass mortalities associated with Viral Nervous Necrosis (VNN) disease in two species of hatchery-rared grouper, Epinephelus fuscogutatus and Epinephelus akaara (Temminck \& Schlegel). J. Fish Dis. 20 185-193.

10. Dai J, Wu Y, Chen S, Zhu S, Yin H, Wang M and Tang J 2010 Sugar compositional determination of polysaccharides from Dunaliella salina by modified RP-HPLC method of precolumn derivatization with 1-phenyl-2-methyl-5-pyrazolone Carbohydrate Polymers. 82 (3) 629-35.

11. Devi A S, Santhanam P, Jeyanthi S and Krishnaveni N 2018 Isolation, culture, and application of marine microalga Dunaliella salina (Volvocales, Chlorophyceae) as an aqua feed additive. Bas. Appl. Phyto. Biol 123-161.

12. Dewi N T B, Aryadi I F, Arrizal A F T, Mardika D R, Syahputra P A, Subekti S, Kismiyati and Sari P D W 2018 Monogenean parasites on cantang grouper (Epinephelus fuscoguttatus- lanceolatus) wilture in floating net cage for mariculture center Lombok, West Nusa Tenggara, Indonesia IOP. Conf. Ser. Earth. Environ. Sci. 137 1-7.

13. Doan Q K, Vandeputte M, Chatain B, Morin T and Allal F 2016 Viral encephalopathy and retinopathy in aquaculture: a review J. Fish. Dis. 40 (5) 717-742.

14. Emadi H, Amaninejad P, Emtiazjoo M and Sahhafi H 2010 Effects of Dunaliella microalgae (Dunaliella salina) on different levels of complement $\mathrm{C}_{3}, \mathrm{C}_{4}$ and antioxidant capacity in rainbow trout (Oncorhynchus mykiss). Adv. Environ. Biol. 4 (3) 456-463.

15. Fenner B J, Thiagarajan R, Chua H K and Kwang J 2006 Betanodavirus B2 is an RNA interference antagonist that facilitates intracellular viral RNA accumulation J. Vir. 80 (1) 85-94.

16. Gibson I K 2016 Goblet cells of the conjunctiva: a review of recent findings. Prog.Retin. Eye Res. 54 49-63.

17. Gupta E, Bhalla P, Khurana N and Singh T 2009 Histopathology for the diagnosis of infectious diseases Indian. J.Med. Microbiol. 27 (2) 100-6.

18. Hashemi Z, Ebrahimzadeh M A and Khalili M 2019 Sun protection factor, total phenol, flavonoid contents and antioxidant activity of medicinal plants from Iran Trop. J. Pharma. Res. 18 (7) 1443-48.

19. Khillare Y K and Wagh S B 1988 Acute toxicity of pesticide in the freshwater fish Barbus stigma: histopatology of stomach Uttar. Pradesh. J. Zoology. 8 176-9.

20. Khumaidi A, Fadjar M, Iranawati F, Kilawati Y and Yanuhar U 2019 Mass mortality associated with viral nervous necrosis of hybrid grouper (Epinephelus $\mathrm{sp}$ ) cultured in city of grouper AIP. Conf. Proc. 2120 (1) 1-8.

21. Martinez-Alvarez R, Morales A E and Sanz A 2005 Antioksidant defenses in fish: biotic and abiotic factors Fish. Biol. Fish. 15 75-88.

22. Ministry of Maritime Affairs and Fisheries 2017 kkp.go.id accessed on 1 September 2019

23. Munday B L, Langdon J S, Hyatt A and Humphrey J D 1992 Mass mortality associated with a viral-induced vacuolating encephalopathy and retinopathy of larval and juvenil barramundi, Lates carcarifer Bloch Aquaclt. 103 (3-4) 197-211.

24. Murphy S P, Choi J C and Holtz R 2004 Regulation of major histocompatibility complex class II gene expression in trophoblast cells Repro. Biol. Endocrinol. 2 (52) 1-8.

25. Nakai T, Mori K, Sugaya T, Nishioka T, Mushiake K and Yamashita H 2009 Current knowledge on viral nervous necrosis (VNN) and its causative betanodaviruses Israel. J. Aquacult. 61 (3) 198-207. 
26. Nazari A, Hassan M D, Zorriehzahra M J, Azmi T I and Arshad S S.2014 Pathogenicity of viral nervous necrosis virus for guppy fish, Poecilia reticulata. Irian. J. Fish. Sci. 13 (1) 168-177.

27. Nishizawa T, Mori K I, Furuhashi M, Nakai T, Furusawa I and Muroga K 1995 Comparison of the coat protein genes of five fish nodaviruses, the causative agents of viral nervous necrosis in marine fish J. Gene. Virol. 76 (7) 1563-69.

28. Pantung N, Helander K G, Helander F B and Cheevaporn V 2008 Histopatological alterations of hybrid walking catfish (Clarias macrocephalus $x$ Clarias gariepinus) in acute and subacute cadmium exposure Environ. Asia. 1 (1) 76-89.

29. Pereira J A, Oliviera I, Sousa A, Valentao P, Andrade P B, Ferreira I C F R, Ferreres F, Bento A, Seabra R and Estevinho L 2007 Walnut (Juglans regia L.) leaves: phenolic compounds, antibacterial activity and antioxidant potential of different cultivars. Food. Chem. Toxycol. 45 2287-95.

30. Praveenraj J , Praveena P E, Bhuvaneswari T, Krishnan A N and Jithendran K P 2018 Experimental infection of betanodavirus in freshwater fish Gambusia affinis (Baird and Girard, 1853) - a potential infection model for viral encephalopathy and retinopathy Aquacult. Inter. 26 (2) 617-27.

31. Robert J R 2001 Fish Pathology, 3 rd Edition (England: Bailere, Tyndall, Cadar) p 300.

32. Rokade Y B and Sayyed R Z 2009 Naphthalene derivatives: a new range of antimicrobials with high therapeutic value Rayasan. J. Chem. 2 (4) 972-80.

33. Rombout J H W M, Taverne N, Kamp M V D and Thiele A J T 1993 Difference in mucuc and serum immunoglobulin of carp (Cyprinus carpio) Dev. Com. Immunol. 17 306-17.

34. Shen H and Vandenabeele P 2014 Necrotic Cell Death (New York: Springer Science+Business Media) p 397.

35. Shin H, Hyuk-Kwon K, Jae-Hyeok L, Xiangai G, Asma A, Jae-Ho K and Doxorubicin S C 2015 Induced necrosis is mediated by poly-(ADP-ribose) polymerase 1 (PARP1) but is independent of p53. Scientific Reports. 5 1-17.

36. Shubin A V, Demidyuk I V, Kmoissarov A A, Rafieva L M and Kostrov S V 2016 Cytoplasmic vacuolization in cell death and survival Oncotarget. 7 (34) 55863-89.

37. Supamattaya K, Kiriratnikom S, Boonyaratpalin M and Borowitzka M 2005 Effect of a dunaliella extract on growth performance, health condition, immune response and disease resistance in black tiger shrimp (Penaeus monodon) Aquacult. 248 (1-4) 207-16.

38. Takshima $F$ and Hibiya $T$ 1995. An atlas of fish histology normal and phatology feature (Tokyo: Kodansha Ltd) p 108.

39. Triastuti J, Pursetyo K T, Monica A, Lutfiyah L and Budi D S 2018 Abnormalities of hybrid grouper (Epinephelus fuscoguttatus $x$ Epinephelus lanceolatus) in Situbondo. IOP. Conf. Ser. Earth. Environ. Sci. 137 1-5.

40. Yahya H M and Wiryanta B T W 2005 Khasiat and Manfaat Buah Merah (AgroMedia: Jakarta) $84 \mathrm{hlm}$.

41. Yang D, Lin J, Chen Y, Liu S, Lu F, Chang T, Wang M, Lin H and Chang Y 2013 Suppresive effect of carotenoid extract of Dunaliella salina alga on production of LPSstimulated pro-inflammantory mediators in RAW264.7 cells via NF-kB and JNK inactivation. J. Function. Food. 5 607-15.

42. Yuwanita $R$, Yanuhar $U$ and Hardoko 2013 Pathognomonic of viral nervous necrotic (VNN) virulence on larvae of humpback grouper (Cromileptes altivelis). Adv. Environ. Biol. 7 (6) 1074-81.

43. Zachary J F 2017 Pathologic Basis of veterinary disease: sixth edition (Missouri: Elsevier) p 1408.

44. Zong W and Thompson C B 2006 Necrotic death as a cell fate. Gen. Develop. 20 1-15. 